Goldschmidt 2021 Abstract

https://doi.org/10.7185/gold2021.8090

\section{Preliminary insights into spodumene trace element composition and speciation}

\author{
CLARA J. BRENNAN, MONA-LIZA C. SIRBESCU, \\ STEPHAN R. HLOHOWSKYJ AND JAMES J. STUDENT \\ Central Michigan University \\ Presenting Author: brenn1cj@cmich.edu
}

Spodumene $\left(\mathrm{LiAlSi}_{2} \mathrm{O}_{6}\right)$ is the main lithium ore mineral found in granitic pegmatites. As a pyroxene, spodumene commonly incorporates trace elements such as $\mathrm{Fe}, \mathrm{Mn}, \mathrm{Sn}$, and $\mathrm{Ga}$, however their crystal-site distribution and speciation is poorly understood. For industrial purposes, identifying how trace metals are incorporated into the spodumene crystal structure is important to the processing of $\mathrm{Li}$ ore. For theoretical purposes, trace element geochemistry of spodumene can reveal information about redox conditions and crystal growth mechanisms in pegmatites. In this study we explore compositional and redox changes during various formation processes of spodumene: primary growth at magmatic to hydrothermal transition, secondary growth as a product of petalite $\left(\mathrm{LiAlSi}_{4} \mathrm{O}_{10}\right)$ breakdown reaction, and growth from hydrothermal fluid. Samples come from Li-rich pegmatite districts including the Black Hills, SD; San Diego Co., CA; Winnipeg River, Manitoba; and Afghanistan.

We performed cathodoluminescence (CL) and X-ray fluorescence (XRF) on spodumene crystals to characterize chemical zoning at various scales. Centimeter-scale core to rim growth zoning was identified in slabbed megacrystals using portable XRF and was further resolved using Bruker micro-XRF and synchrotron-XRF at Advanced Photon Source, Argonne National Laboratory. Average LA-ICP-MS concentrations evolved from core to rim zones of a magmatic megacrystal from 700 to $350 \mathrm{ppm}$ for $\mathrm{Mn}$ and 2000 to $2500 \mathrm{ppm}$ for $\mathrm{Fe}$. Micrometer-scale oscillatory growth zoning in secondary spodumene was identified with CL and synchrotron-XRF (Fig. 1). Spodumene from the Helen Beryl mine, $\mathrm{SD}$ averaged the highest concentrations of $\mathrm{Mn}$ and Fe: 750 and $9600 \mathrm{ppm}$, respectively. Overall secondary spodumene was purer than primary magmatic spodumene, with "high" concentration zones averaging $200 \mathrm{ppm} \mathrm{Mn}$ and $200 \mathrm{ppm} \mathrm{Fe}$, and "low" zones averaging $60 \mathrm{ppm} \mathrm{Mn}$ and $40 \mathrm{ppm}$ Fe.

Preliminary X-ray absorption spectroscopy (XAS) measurements suggest that coordination and oxidation states of $\mathrm{Mn}$ and $\mathrm{Fe}$ vary with the genetic type and within zones of individual crystals (Fig. 2). To calibrate the Fe and Mn XANES results, we will study the effects of spodumene crystallographic orientation relative to the incident beam on the pre-edge and XANES features. Combined trace-element contents and speciation in spodumene may improve our understanding of pegmatite magma crystallization conditions.

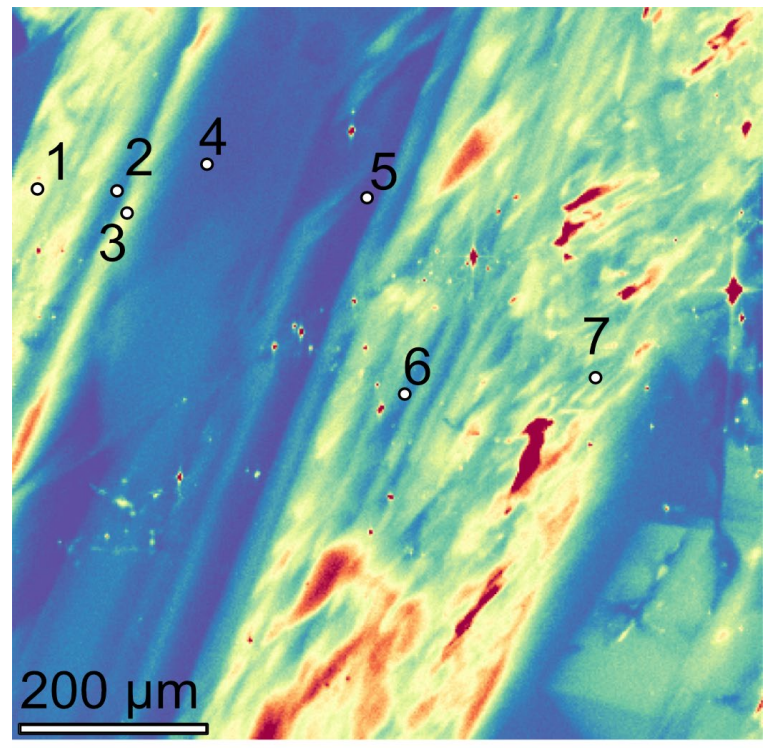

Figure 1. Synchrotron XRF map of Mn zoning in spodumene from Dibs pegmatite, Winnipeg River, Manitoba

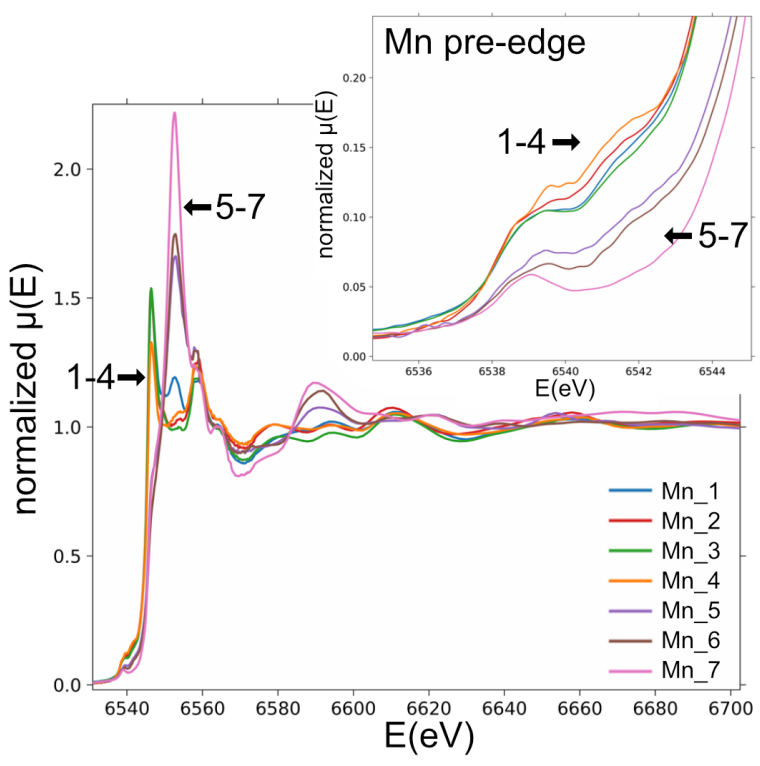

Figure 2. Preliminary Mn XAFS spectra from zoned spodumene from Dibs pegmatite, Winnipeg River, Manitoba 